\title{
The Online Social Support of Chinese Fellow Townsman in Post Pandemic
}

\author{
Ning Gao \\ School of Journalism and Communication, Nanjing Normal University, Nanjing, China \\ 1223316646@qq.com \\ Diserahkan: 7 Juni 202 1; Direvisi: 27 Juni 2021; Diterima: 27 Juni 2021
}

\begin{abstract}
As a kind of disease risk, the global spread of the COVID-19 may just be a microcosm of the global risk society. Affected by the epidemic, people adopt more online virtual connections and have become more dependent on social media. This paper conducted the online social support of Chinese fellow-townsman analysis via conducting online participatory observations on the QQ group of Xinhua immigrants and conducting in-depth interviews with 15 of them. This study found that the social support obtained by the Chinese Fellow Townsman through the Internet interpersonal mutual aid network has made up for the shortcomings of formal social support to a certain extent. In the risk society, it helps individuals get immediate and personalized help. In terms of online social support sources, the Internet social support of Chinese Fellow Townsman mainly comes from bridging social capital. From the perspective of online support content, the online social support of this group is mainly manifested in emotional support, companionship support, and informational support, and the role of tangible support is relatively weak. As to the support effect, through the Online social support from the group, the peers can obtain timely, diverse, and non-redundant information to help them make better decisions. But the ability of interpersonal networks to provide resources is limited. When necessary, we still need social support from the government and other formal organizations.

Keywords: Chinese Fellow Townsman, Online Social Support, Social Media, Risk Society.
\end{abstract}

\section{Abstrak}

Sebagai jenis risiko penyakit, penyebaran global COVID-19 mungkin hanya merupakan mikrokosmos dari masyarakat risiko global. Dipengaruhi oleh epidemi, orang mengadopsi lebih banyak koneksi virtual online dan menjadi lebih bergantung pada media sosial. Makalah ini melakukan analisis dukungan sosial online dari sesama warga kota Cina melalui pengamatan partisipatif online pada kelompok QQ imigran Xinhua dan melakukan wawancara mendalam dengan 15 dari mereka. Studi ini menemukan bahwa dukungan sosial yang diperoleh oleh Warga Kota China Fellow melalui jaringan bantuan timbal balik antarpribadi Internet telah menutupi kekurangan dukungan sosial formal sampai batas tertentu. Dalam masyarakat risiko, ini membantu individu mendapatkan bantuan langsung dan personal. Dalam hal sumber dukungan sosial online, dukungan sosial Internet dari Chinese Fellow Townsman terutama berasal dari modal sosial yang menjembatani. Dari perspektif konten dukungan online, dukungan sosial online kelompok ini terutama diwujudkan dalam dukungan emosional, dukungan persahabatan, dan dukungan informasi, dan peran dukungan nyata relatif lemah. Mengenai efek dukungan, melalui dukungan sosial Online dari grup, teman sebaya dapat memperoleh informasi yang tepat waktu, beragam, dan tidak berlebihan untuk membantu mereka membuat keputusan yang lebih baik. Tetapi kemampuan jaringan antarpribadi untuk menyediakan sumber daya terbatas. Bila perlu, kami masih membutuhkan dukungan sosial dari pemerintah dan organisasi formal lainnya.

Kata kunci: Warga Tionghoa Sesama, Dukungan Sosial Online, Media Sosial, Masyarakat Berisiko. 


\section{INTRODUCTION}

In March 2020, the World Health Organization anxiously announced that the COVID-19 has the characteristics of a pandemic (World Health Organizations, 2020) The pandemic has lasted for more than one year. According to WHO, as of Mid-March this year, there have been nearly 120 million confirmed cases of COVID-19, including more than 2.6 million deaths. The pandemic put global communities at vulnerability. Dr. Soumya Swaminathan, Chief Scientist of the WHO predicted that pandemic will finally under the control within four or five years (Hodgson, 2013).

It was accidental that the COVID-19 from nature spread among people and then developed into a global plague. However, the spread of the epidemic of various countries and its disastrous consequences are also inevitable. As the case of COVID-19 continue to climb, people concern about the disease and population is growing vulnerability. At present, our society has entered the era of a global risk society characterized by high uncertainty and high complexity. As a kind of disease risk, the global spread of the COVID-19 may only be a microcosm of the global risk society.

From the prespective of Ulrich Beck a "risk society" and a "world risk society" have been developed on a worldwide scale, with new hazards, dangers, security concerns, and life uncertainties that cannot be managed nationally or by the state. According to Beck, people are no longer living in a civilization that is "behind the modern," but instead are heading into the era of the "other modern," in which contemporary global institutions that destroy the conventional ones the "classic" or, as it is commonly referred to, the old industrial society is fading away, and a new risk society, as well as a global risk society is emerging. People could call this the emergence of a "global risk society." Ulrich Beck uses the term risk society to describe a society that is more advanced than an industrial society, in which the "creation of goods is systematically followed by the social production of risk."

To mitigate with COVIDo19 pandemin, as part of global risk society many governments and charity organizations have taken measures to support people. However, it could not help individuals solve all problems. It is particularly evident in this pandemic. In addition to the social support provided by formal social organizations, individuals can also obtain social support to resist the social risks of interpersonal mutual aid networks. With the popularization of ICTs, we are entering a mediated society (Yuchen, 2018). Affected by the epidemic, people adopt more online virtual connections and have become more dependent on social media. As we are in the globalization era, the life of people or society and media is intertwined (Livingstone \& Lunt, 2014).

From the perspective of Livingstong and Lunt (2014) mediatizations works on domains of society, they can be instutional and norms, resources and expertise, politics, religion, educations, cultural order, etc (Livingstone \& Lunt, 2014). In this case, the reseacher would like to specify on rural-urbal immigrant in China during COVID-19 pandemic. The immigrant that came to China need certain assistants integrating with Chinese society. Meanwhile during COVID-19 pandemic, the authorities have recommended a number of behavioural adjustment to prevent further infection to the minimum and to prevent the virus from spreading to the vast majority of the population by means of physical isolation. This is including, measurement as community lockdowns, stay-at-home orders and social distancing regulations (Bian, 2020).

Because of these adjustment and physical isolations, it is hard to meet people, particularly to those immigrant who need assistant. This study believe within the mediatization and online support can support the immigrant. Thus, we should also pay attention to the important role of online social support provided by interpersonal networks. Therefore, this study hopes to take the rural-urban immigrants in China as an example to examine the role of social support provided by the extended interpersonal network of the Internet space in resisting social risks 


\section{LITERATURE REVIEW}

\section{RISK SOCIETY THEORY IN THE CONTEXT OF POST-PANDEMIC}

The Risk Society Theory in the Context of post-pandemic. The first scholar that put forward the theory of risk society was Ulrich Beck. In his view, human society and risk coexist (Beck, 1992). He defined scoial risks as part of daily lives of human beings. He also argued that social risk as a systematic way of dealing with the perils and insecurities resulting from modernization. He attributed this issue to broad change, which he called "reflexive modernization", where the unintended and unpredictable impacts of modern lige on modernity take place. However, in modern society, manufactured risk replaces the external risk originating from the end of nature and the end of tradition as the dominant risk (Beck, 2002)

Anthony Giddens expanded on the theory of risk society. He believes that in the second half of the 20th century, human society has become a high-risk society (Giddens, 2018). He also emphatically distinguishes the external risks and man-made risks (Giddens, 2013). External risks refer to the risks that may cause losses to humans, such as natural, physiological, or social phenomena, and are often estimated at the basis of time series. As to man-made risks, they refer to the risks arising from the impact on human development on the world, which is often risks when we lack historical experience.

On the basis of the existing theories, Niklas Luhmann in 2003 summarized and put forward the risk system theory, and linked risk of human decision-making. He not only emphasized the human and social factors of risk but also emphasized the impact on the risk of the future (Luhmann, 2003). To overcome risks, it is necessary to reconstruct the functional system to control the abnormal growth of social power and interests. The research of scholars represented by Ulrich Beck, Anthony Giddens, and Niklas Luhmann has promoted the development of risk society-related theories. After experiencing many global unanticipated risks, risk society has become an important concept for people to understand and analyze modern society. Risk society does not merely arise from the reality that daily life has generally become more dangerous, the problem is more about fading the borders of uncontrollable risks (Ritzer, 2004).

According to scholars 'interpretation of risk society, we can understand the COVID-19 as a combination of "man-made risks" and " external risks". In other words, the risk of the epidemic is more like a risk that originates from nature but is amplified by human behavior or human life. From this perspective, the current outbreak should be considered an opportunity to make significant changes in future life. It could be argued that coronavirus is the invasion of reality and kind of a slap in the face of the individualistic world, requiring social solidarity, empathy, cooperation, and moralization. The epidemic has had a profound impact on human society, and it has also affected the media industry and social information systems. We should pay attention to the impact on the COVID-19 risk of media and society.

\section{CHANGES IN CHINESE DISSEMINATION ENVIRONMENT DURING THE POST-PANDEMIC}

The epidemic has changed the Chinese media environment. On the one hand, it has caused the infodemic in terms of information dissemination, which refers to a combination of information and epidemic. This concept mainly define to the process of intensifying the epidemic due to excessive information. The concept originally referred to the phenomenon that after the SARS outbreak in 2002, the epidemic was exacerbated due to excessive information (Rothkopf, 2003).

Infodemic can be defined as a mixed of fear, speculation and rumour, amplified and spreaded worlwide by modern information and technologies. It has affected multifaceted effect on national and international level, such as on economics, cultures, politics, most of them are challenging because of disproportion with the facts and realities. During SARS pandemic in the 2002, infodemic was not the rapid spread of simple news via the media. Rather, it is a complex phenomenon caused by the interaction of mainstream media, specialist media and internet sites, and "informal" media during 
that time, which was to say wireless phones, text messaging, pagers, faxes and e-mail, all transmitting some combination of fact, rumor, interpretation and propaganda.

Multiple languages, cultures, and attitudes toward the free and open flow of information might make it more difficult to comprehend. It encompasses information consumers ranging from government officials to ordinary citizens, all of whom have variable ability to grasp the big picture, varying degrees of expertise in terms of what to do with the data they have, and limited opportunities to verify data before acting on it and little to no training in comprehending or controlling the rapidly changing information landscape.

In correlation with the infodemic during SARS eighteen years ago, at present the popularization of information technologies such as smartphones and social media has made Chinese society appear increasingly mediated. Also, the communication activities have become an important part of human a. The "infodemic" brought about by the new crown epidemic has a greater impact than atypical pneumonia. This is specifically manifested in the following three aspects: a) It brings people excessive fear and anxiety. b) It makes it difficult for people to make correct judgments and blindly follow false information to perform wrong actions. c) It causes misunderstandings among people, Intensifying the antagonism and conflict between races.

On the other hand, the epidemic has made people pay attention to maintaining offline social distance, which has also strengthened the close connection between media technology and people's lives. The acceleration of technology driven by the epidemic has accelerated the digital transformation of all walks of life, too (Lan, 2020; Shuang, 2020). At the same time, the isolation from physical space intensifies the connection with virtual space. More and more people rely on social media to obtain and produce information and rely on social terminals to engage in social activities such as communication, production, consumption, and education (Xingyu, 2020).

\section{THE DEVELOPMENT OF SOCIAL NETWORK AND SOCIAL CAPITAL RELATED THEORIES IN THE CHINESE SOCIAL CONTEXT}

The social network refers to a set of points or network members connected by one or more relationships. The concept of social network analysis is that social existence is constituted primarily and most profoundly by relationships and the patterns formed by these relationships. Formally, social networks are described as a collection of nodes (or network members) linked by one or more types of relationships. (Wasserman \& Faust, 1994). Following the basic idea from Wasserman and Faust (1994), Marina and Wellman (2011) defines social network as connected by one or more relations. Nodes, or network members, are the units that are connected by the relations whose patterns we study. These units are most commonly persons or organizations, but in principle any units that can be connected to other units can be studied as nodes (Marina \& Wellman, 2011)

Meanwhile scholar Fei Xiaotong developed the theory of social networks based on the Chinese context. He used the concept of " Diversity-orderly Structure", which is similar to "the overlapping of egocentric networks", to explain the social network that Chinese people value blood and geography. Social support is a concept related to social network resources. It refers to the tangible or intangible help that an individual receives from his network members (Berkman, 1984). Bjornsdottir G's research (1999) on Internet social support for patients with heart disease is the earliest research on Internet social support. The theory of social support has been recognized and accepted by Chinese scholars, who continue to develop the theory about the Chinese context. In addition to the field of health, the Chinese research objects of Internet social support also show a trend of diversification, such as the research on Internet social support of overseas students (Ran, 2017), online car Hailing drivers (Xi, 2019), migrant workers (Xin, 2017).

\section{METHODS}

In China, most of the practitioners in the printing industry near universities come from Xinhua County, Hunan Province (Junqi, 2010). The rural social network of the Chinese Xinhua immigrants 
formed into the basis of kinship, geography, and blood ties play an important role in the process of their integration into the city. With the development and popularization of media such as the Internet, current social relations largely rely on online and offline communication activities to maintain.

In-depth interviews are a qualitative research method that can help us understand the motives, behaviors, goals, attitudes, and feelings of interviewees and discover the inner logic of things. This paper conducted the online social support of Chinese fellow-townsman analysis via conducting online participatory observations on the QQ group of Xinhua immigrants and conducting in-depth interviews with 15 of them. The basic information on the interviewee is shown in Table I. The research will focus on answering such a question: What kind of Internet social support does the Chinese fellow-townsman use to resist uncertain risks in post-pandemic? Support behavior, support source, and support effect will be the three important dimensions of investigation.

Table 1. Basic Information of the Respondent

\begin{tabular}{|c|c|c|}
\hline Number & Age & Entry Year \\
\hline S1 & 25 & 2015 \\
\hline S2 & 27 & 2002 \\
\hline S3 & 22 & 2019 \\
\hline S4 & 24 & 2019 \\
\hline S5 & 38 & 2009 \\
\hline S6 & 21 & 2017 \\
\hline S7 & 22 & 2017 \\
\hline S8 & 19 & 2017 \\
\hline S9 & 27 & 2001 \\
\hline S10 & 32 & 2010 \\
\hline S11 & 24 & 2019 \\
\hline S12 & 19 & 2019 \\
\hline S13 & 23 & 2017 \\
\hline S14 & 21 & 2016 \\
\hline S15 & 25 & 2018 \\
\hline
\end{tabular}

\section{RESULT AND DISCUSSION}

The social support obtained by the Chinese fellow-townsman through the Internet interpersonal mutual aid network has made up for the shortcomings of formal social support to a certain extent. In a risk society, it helps individuals get immediate and personalized help. Social capital is the direct source of social support. In terms of online social support sources, the Internet social support of Chinese fellow-townsman mainly comes from external social capital. It includes acquaintances outside the intimate circle, online networks, and channels into people to exchange information on each other, usually composed of weak ties (Bian, 2020). This also facilitates them to obtain more heterogeneous social support. As one respondent said, "to be honest, when I have difficulties and need help, I tend to ask my friends with the QQ group for help. Because my relatives and I am very close, I feel uncomfortable always ask them for help. Seeking help from fellow-townsman of the same age will make me feel better. During the epidemic, I was also more inclined to express my nervousness and anxiety about the epidemic in group chats. The responses also helped me a lot" (S7).

During the epidemic, the social support of this group is mainly informational support, emotional support, and companionship support, and tangible support is in a relatively marginal position. The results of the in-depth interviews also show that Chinese fellow townsman who is good at using 
Internet social support can better relieve pressure, get more information, and group companionship during the epidemic, in order to deal with the isolation of the real space and the emotional aspects brought about by the epidemic. For instance, a respondent said: When the epidemic was severe, my business was very bad, and chatting with fellow townsmen in groups effectively alleviated my anxieties. (S11) Another respondent also revealed that: During the days when masks were hard to buy, the exchanges of fellow townsmen in the group made it easier for me to obtain epidemic prevention materials $(\mathrm{S} 2)$.

As to the support effect, through the online social support from the group, the peers can obtain timely, diverse, and non-redundant information to help them make better decisions. One interviewee recalled the important role of online social support in helping him make decisions on the epidemic, he claimed that: When the epidemic was severe last year, something bad happened to the home and I was anxious to go back. I urgently need to know the epidemic prevention policy of my hometown, but the phone number of the epidemic prevention department in my hometown is always busy (That is, someone else is asking). Therefore, I asked the fellows of the group for help, and soon some of them responded to me with relevant information. I thought about it carefully and finally chose to hurry back to my hometown (S4).

The social support obtained by the Chinese Fellow Townsman through the Internet interpersonal mutual aid network has made up for the shortcomings of formal social support to a certain extent. Not only the Chinese, but Indonesians, Africans, and Europeans all have similar offline strong social relationships that extend in the Internet space, such as kinship networks, blood relationship networks, and geographical area networks. We should value the important role that these online social support networks to play in providing social support against unknown risks.

It helps individuals get immediate and personalized help. In a risky society, the society know which comes first, happiness or misfortune. People value the important role that these online social support networks play in providing social support against risks that are unknown to the risk community. But a good online social support community requires the joint efforts and efforts of all members. So human should be the positive provider of social support and improve the quality of resources in the online social network.

\section{CONCLUSION}

However, the ability of interpersonal networks to provide resources is limited. On the one hand, it is impossible to help individuals effectively cope with macro-social structure problems. For instance, the government introduces appropriate measures to deal with epidemics. Solving such problems still requires the support of formal organizations such as the government. On the other hand, the resources that networks provide can only help them solve the problem at hand, many of the solutions are based on personal experience, and the quality of the information is poor. There are some things that people don't share among online communities. For example, one interviewee reclaimed that: Everyone was actively speaking to the crowd, but once someone wanted to borrow money, the crowd became silent. (S2) It can be seen that when individuals need financial assistance and other rigid support, they should still seek the help of the government and other formal social organizations. In addition, the good and bad support information and the excessive dependence on the support within the groups are not conducive to the long-term development of the online group. Therefore, we must pay attention to operating our own Internet interpersonal mutual assistance network and improve the quality of social capital in it, so as to be more flexible in dealing with unknown risks.

\section{ACKNOWLEDGEMENT}

Thank the organizers of the 3rd Jogjakarta Communication Conference and Jurnal Audiens for giving me this opportunity to communicate with researchers from all over the world. At the same time, I would also like to thank the QQ group owners and interviewees who allowed me to conduct non-participatory observations in group chats. 


\section{REFERENCES}

An, R., \& Chen, W.-c. (2017). Research in Social Support of Mobile Communication Media for International Students. Journal of Xinjiang Normal University(Edition of Philosophy and Social Sciences), (01),131-137.

Beck, U. (2002). Risk society revisited: theory, politics, and research programs. In, The risk society and beyond: critical issues for social theory. In U. B. B. Y. Adam. London: Sage.

Beck, U. L. (1992). Risk society: Towards a new modernity. London: Sage Publications.

Berkman, L. F. (1984). Assessing the physical health effects of social networks and social support. Annual review of public health, 5(1), 413-432.

Bian, Y. (2020). Epidemic-specific social capital and its impact on physical activity and health status. Journal of Sport and Health Science.

Bjornsdottir, G. (1999). Online social support for individuals concerned with heart disease: observing gender differences. . In Proceedings of the AMIA Symposium: American Medical Informatics Association, 681.

Giddens, A. (2013). The consequences of modernity. John Wiley \& Sons.

Giddens, A. (2018). Runaway world: How globalization is reshaping our lives. Taylor \& Francis.

Hodgson, C. (2013, May). WHO's chief scientist offers bleak assessment of challenges ahead. Retrieved 2021, from Financial Times Website: https://www.ft.com/content/69c75de6-9c6b-4bcab110-2a55296bo875

Junqi, F. (2010). The Forming of Xinhua Phenomenon. Social Sciences of Beijing(02, 47-53.

Lan, P. (2020). How Should We Build the Public Information Dissemination System in New Media Age? . Journalism and Mass Communication Monthly Vol. 05, 36-43.

Livingstone, S., \& Lunt, P. (2014). Mediatization: an emerging paradigm for media and communication studie. In K. Lundby, Handbooks of Communication Sciences (pp. 703-724). Berlin: De Gruyter Mouto.

Luhmann, N. (2003). Soziologie des risikos. de Gruyter.

Marina, A., \& Wellman, B. (2011). Social Network Analysis: An Introduction. In J. Scott, \& P. J. Carrington, The SAGE Handbook of Social Network Analysis. London: SAGE Publications.

Ritzer, G. (2004). Encyclopedia of social theory. London: Sage Publications.

Rothkopf, D. (2003, May 11). When the Buzz Bites Back. Retrieved 2021, from Udel edu website: Retrived from: .http://www 1.udel.edu/globalagenda/2004/student/readings/infodemic.html.

Shuang, L. (2020). 经济导向与文化环境——当代老年群体数字鸿沟的形成路径. Journalism Lover Vol. 10, 92-93.

Wasserman, S., \& Faust, K. (1994). Social network analysis: Methods and applications.

World Health Organizations. (2020, March 11). World Health Organization WHO Director-General's opening remarks at the media briefing on COVID-19-11 March 2020. Retrieved 2020, from WHO website: https://www.who.int/director-general/speeches/detail/who-directorgeneral-s-opening-remarks-at-the-me

Xi, Z., Xu, W., \& Baiyu, L. (2019). Journalism \& Communication Vol. 06. Study on the Network Structure and Social Support in the DiDi Drivers' Mobile Community, 36-58.

Xin, Z., Qian, C., \& Fang, W. (2017). Investigation and Analysis of Information Services of Tianjin Public Library for Migrant Workers-Based on Social Support Theory. Library \& Information Vol. O2, 76-83.

Xingyu, Z. (2020). . 终端化生存 后疫情时代的城市升维. Time + Architecture Vol. 4, 90-93.

Yuchen, D. (2018). Mediatization Study: A New Paradigm Shift in Communication Research. . Journal of Anhui University Philosophy and Social Sciences Edition Vol. O2, 147-156. 